\title{
Co-occurrence patterns and the large-scale spatial structure of benthic communities in seagrass meadows and bare sand
}

\author{
Casper Kraan ${ }^{1,2,5}$ (D) Simon F. Thrush ${ }^{3}(\mathbb{D})$ and Carsten F. Dormann ${ }^{4^{*}}$ (])
}

\begin{abstract}
Background: Species distribution models are commonly used tools to describe diversity patterns and support conservation measures. There is a wide range of approaches to developing SDMs, each highlighting different characteristics of both the data and the ecology of the species or assemblages represented by the data. Yet, signals of species co-occurrences in community data are usually ignored, due to the assumption that such structuring roles of species co-occurrences are limited to small spatial scales and require experimental studies to be detected. Here, our aim is to explore associations among marine sandy-bottom sediment inhabitants and test for the structuring effect of seagrass on co-occurrences among these species across a New Zealand intertidal sandflat, using a joint species distribution model (JSDM).

Results: We ran a JSDM on a total of 27 macrobenthic species co-occurring in $300,000 \mathrm{~m}^{2}$ of sandflat. These species represented all major taxonomic groups, i.e. polychaetes, bivalves and crustaceans, collected in 400 sampling locations. A number of significant co-occurrences due to shared habitat preferences were present in vegetated areas, where negative and positive correlations were approximately equally common. A few species, among them the gastropods Cominella glandiformis and Notoacmea scapha, co-occurred randomly with other seagrass benthic inhabitants. Residual correlations were less apparent and mostly positive. In bare sand flats shared habitat preferences resulted in many significant co-occurrences of benthic species. Moreover, many negative and positive residual patterns between benthic species remained after accounting for habitat preferences. Some species occurring in both habitats showed similarities in their correlations, such as the polychaete Aglaophamus macroura, which shared habitat preferences with many other benthic species in both habitats, yet no residual correlations remained in either habitat.

Conclusions: Firstly, analyses based on a latent variable approach to joint distributions stressed the structuring role of species co-occurrences beyond experimental scales. Secondly, results showed context dependent interactions, highlighted by species having more interconnected networks in New Zealand bare sediment sandflats than in seagrass meadows. These findings stress the critical importance of natural history to modelling, as well as incorporating ecological reality in SDMs.
\end{abstract}

Keywords: Co-occurrence, Environmental variation, Intertidal, Joint species distribution model, Seagrass meadows

*Correspondence: carsten.dormann@biom.uni-freiburg.de

${ }^{4}$ Biometry and Environmental System Analysis, University of Freiburg,

Tennenbacherstr. 4, 79106 Freiburg, Germany

Full list of author information is available at the end of the article

\section{Background}

Co-occurrence patterns of species across a landscape may arise due to shared habitat preferences, dispersal patterns, community interactions (e.g. facilitation, competition) or the interaction of these processes [1, 2]. This interest in joint distributions of species relates

(c) The Author(s) 2020. This article is licensed under a Creative Commons Attribution 4.0 International License, which permits use, sharing, adaptation, distribution and reproduction in any medium or format, as long as you give appropriate credit to the original author(s) and the source, provide a link to the Creative Commons licence, and indicate if changes were made. The images or other third party material in this article are included in the article's Creative Commons licence, unless indicated otherwise in a credit line to the material. If material is not included in the article's Creative Commons licence and your intended use is not permitted by statutory regulation or exceeds the permitted use, you will need to obtain permission directly from the copyright holder. To view a copy of this licence, visit http://creativeco mmons.org/licenses/by/4.0/. The Creative Commons Public Domain Dedication waiver (http://creativecommons.org/publicdomain/ zero/1.0/) applies to the data made available in this article, unless otherwise stated in a credit line to the data. 
to (1) incorporating real-world complexity in species distribution models (SDM) by allowing species to interact [3], and (2) solving technical challenges posed by having to extend generalized linear mixed models to multivariate models that allow us to separate correlation patterns across multiple species from environmental responses [1].

Biotic interactions have been experimentally shown to be important drivers of local community structure in many different kinds of ecological systems (e.g. [4]). Their role in driving patterns at a larger scale, even determining species ranges, is less well established, although clear examples exist [3,5]. At large scales, manipulative experiments are unfeasible, and detection of interactions relies on correlative evidence, recently in the form of joint analyses of species abundances or occurrences (joint species distribution models: JSDMs). With this method, environmental drivers of species distributions are accounted for, and remaining correlation in the model residuals indicate association between species, often interpreted as biotic interactions (e.g. [6, 7]).
Competitive and facilitative interactions may arguably be stronger among near-sessile organisms, such as plants, parasites, or indeed benthic invertebrates [8]. Structure provided by the habitat may substantially affect the way such interactions play out, providing physical shelter or habitat for predators [9]. Here, our aim is employing macroecological techniques to explore associations among marine sandy-bottom sediment inhabitants and test for the structuring effect of seagrass on co-occurrences among these species. Specifically, we test the hypothesis that macrozoobenthic communities in seagrass patches (Zostera muelleri) maintain more interconnected interaction networks across intertidal areas than the same species communities inhabiting intertidal sandflats (Fig. 1). This reflects the common assumption that seagrass meadows, due to their structural complexity, play a significant role in maintaining diversity and resilience of coastal systems $[10,11]$.

Our main interest lies in the ecological inference possible from multi-species models. We acknowledge the technical challenges and great benefits of employing JSDMs and refer to $([1,12]$ and references cited herein)

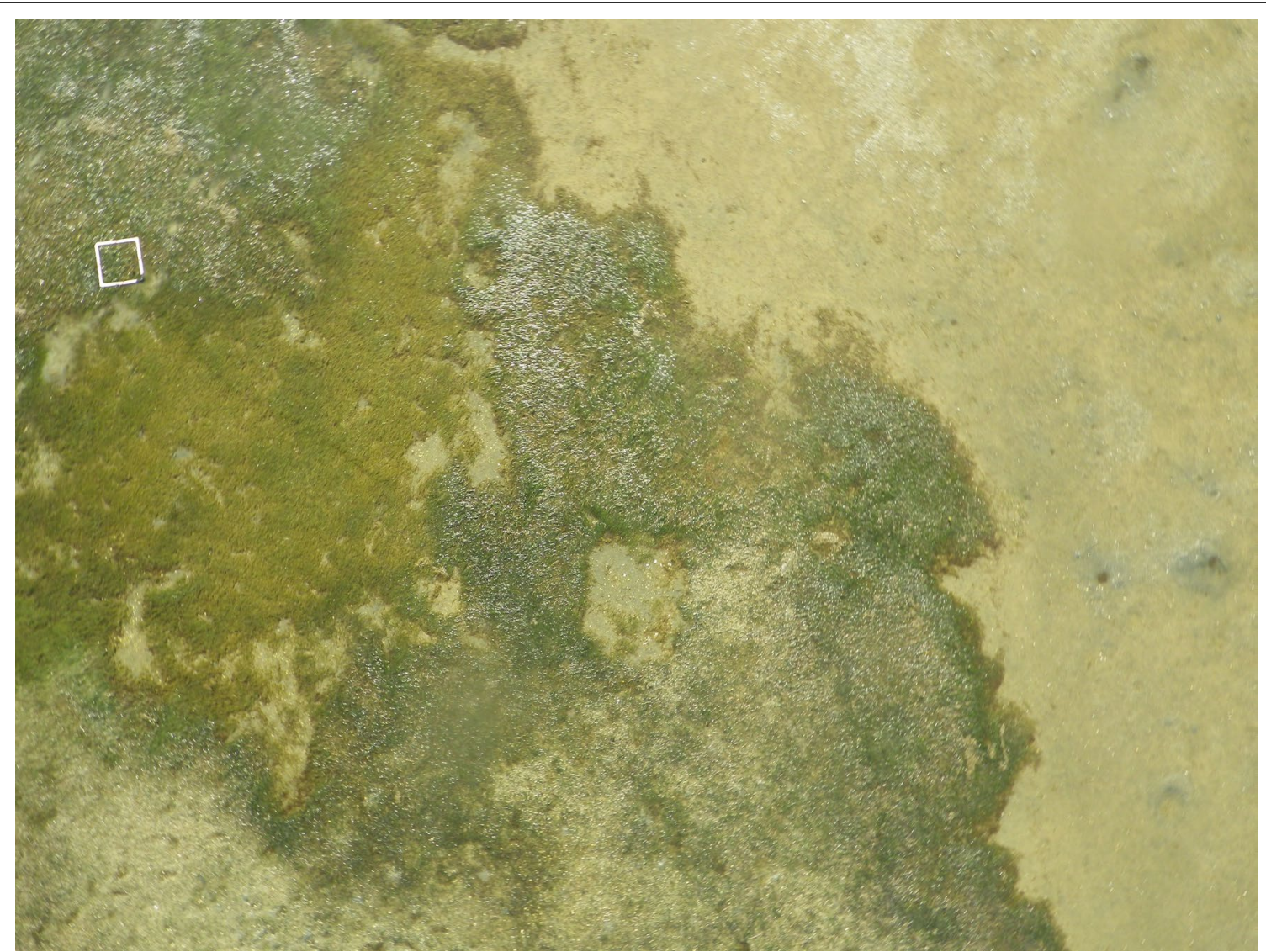

Fig. 1 An illustration of the visual contrast between seagrass meadows (left hand side) and bare sediment sandflats (right hand side). Picture taken by Roman Zajac at Kaipara harbour, New Zealand. The white rectangle encompasses $0.5 \times 0.5 \mathrm{~m}$ 
for mathematical comparisons between modelling choices. To address the lack of knowledge regarding the structuring role of species co-occurrences across landscapes, our work employed latent variable models (LVM) and demonstrated their advantages for studying multi-species distributions. LVMs are emerging as efficient tools to dissect multivariate data $[1,13]$, since they explicitly link latent variables to each sample as unobserved predictors to capture unobserved environmental predictors [1] or non-random co-occurrences. We showed that patterns in species co-occurrences were context dependent and structure communities across spatial scales of at least $1 \mathrm{~km}$, as illustrated by comparing marine species communities in seagrass meadows to the same species occupying bare intertidal sandflats. These results have implications for most current SDM research, which are mainly employing single-species models.

\section{Results}

We ran a joint species distribution analysis on a total of 27 species co-occurring in $300,000 \mathrm{~m}^{2}$ of New Zealand intertidal sandflat, representing all major taxonomic groups, i.e. polychaetes, bivalves and crustaceans. Eleven species only occurred in seagrass meadows, 6 species were restricted to bare sand flats, whereas 10 species were common ( $>25 \%$ of sampling locations) to both habitats (Table 1).

A number of significant co-occurrences due to shared habitat preferences were present in vegetated areas (Fig. 2), where negative and positive correlations were approximately equally common. A few species, among

Table 1 Species descriptions and information on their occurrences ( $n$ sampling locations) and abundances (mean count) in seagrass (coverage at least $33 \%)$ and bare-sand systems ( $0 \%$ coverage of seagrass)

\begin{tabular}{|c|c|c|c|c|}
\hline & & & Seagrass & Bare sand \\
\hline & & $n$-samples & 63 & 279 \\
\hline Species & Abbreviation & Taxonomic group & Occurrence (mean) & Occurrence (mean) \\
\hline Aglaophamus macroura & aglmac & Polychaetes & $16(0.46)$ & $99(0.52)$ \\
\hline Aonides trifida & aontri & Polychaetes & $36(2.87)$ & $161(12.35)$ \\
\hline Arthritica bifurcata & artbif & Bivalves & $15(0.60)$ & \\
\hline Austrovenus stutchburyi & ausstu & Bivalves & $33(3.97)$ & $146(1.71)$ \\
\hline "Bumpy" cirrisyllid & bumcir & Polychaetes & $15(0.60)$ & $97(1.19)$ \\
\hline Colurostylus lemurum & collem & Crustaceans & & $176(1.63)$ \\
\hline Cominella glandiformis & comgla & Gastropods & $22(0.62)$ & \\
\hline Halicarcinus varius & halvar & Crustaceans & $15(0.40)$ & \\
\hline Halicarcinus whitei & halwhi & Crustaceans & $15(0.43)$ & \\
\hline Hesionidea & hesion & Polychaetes & & $97(0.68)$ \\
\hline Heteromastus filiformis & hetfil & Polychaetes & $36(1.16)$ & $145(1.44)$ \\
\hline Macomona liliana & maclil & Bivalves & $61(3.89)$ & $261(7.00)$ \\
\hline $\begin{array}{l}\text { Macroclymenella stewartensis stew- } \\
\text { ardensisstewartensis }\end{array}$ & macste & Polychaetes & $26(0.97)$ & \\
\hline Magelona dakini & magdak & Polychaetes & & $152(1.66)$ \\
\hline Nemertean & nemert & Polychaetes & $30(1.02)$ & $202(2.19)$ \\
\hline Notoacmea scapha & notsca & Gastropods & $24(0.71)$ & \\
\hline Nucula hartvigiana & nucchar & Bivalves & $45(2.03)$ & $95(1.65)$ \\
\hline Orbinia papillosa & orbpap & Polychaetes & & $100(0.95)$ \\
\hline Owenia petersonae & owepet & Polychaetes & $20(1.16)$ & \\
\hline Paphies australis & papaus & Bivalves & $19(0.51)$ & $133(5.07)$ \\
\hline Paracalliope novizealandiae & parnou & Crustaceans & $30(5.22)$ & $103(1.05)$ \\
\hline Phoronis sp. & phoron & Other & & $91(1.17)$ \\
\hline Platynereis australis & plaaus & Polychaetes & $25(0.59)$ & \\
\hline Prionospio aucklandica & priauc & Polychaetes & $31(2.37)$ & \\
\hline Pseudopolydora 'FAT' & psefat & Polychaetes & $27(1.06)$ & \\
\hline Soletellina siliqua & solsil & Bivalves & & $155(3.56)$ \\
\hline Trochodota dendyi & troden & Polychaetes & $22(0.46)$ & \\
\hline
\end{tabular}




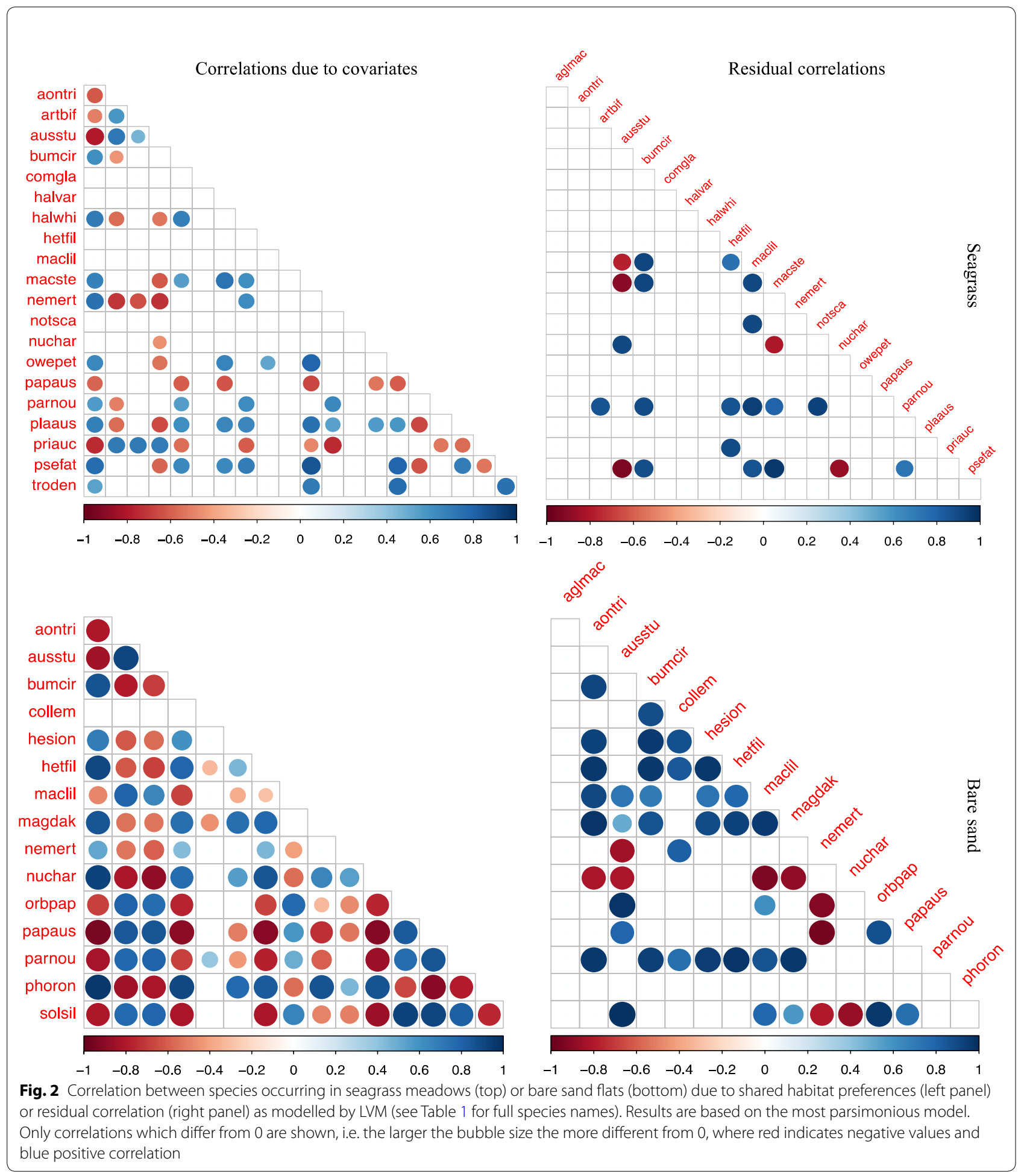

them the gastropods Cominella glandiformis and Notoacmea scapha, co-occurred randomly with other seagrass benthic inhabitants, as indicated by an empty row of raw correlations (Fig. 2). Residual correlations were less apparent and mostly positive (Fig. 2). Austrovenus stutchburyi, a common suspension-feeding bivalve, was the only species to display negative residual correlations with more than a single species, i.e. the deposit-feeding bivalve 
Macomona liliana and two tube-building polychaetes Macroclymenella stewartensis and Pseudopolydora 'FAT.

In bare sand flats shared habitat preferences resulted in many significant co-occurrences of benthic species. Moreover, many negative and positive residual patterns between benthic species remained after accounting for habitat preferences (Fig. 2). Most noteworthy, the deposit-feeding bivalve Nucula hartvigiana was negatively correlated with deposit-feeding polychaetes Aonides trifida and Magelona dakini, the suspension-feeding bivalves A. stutchburyi and Soletellina siliqua, and the deposit-feeding bivalve $M$. liliana.

Some species occurring in both habitats showed similarities in their correlations, such as the polychaete Aglaophamus macroura, which shared habitat preferences with many other benthic species in both habitats, yet no residual correlations remained in either habitat. The amphipod Paracalliope novizealandiae not only cooccurred with many other species in both habitats, but also displayed positive residual correlation with six or more species in each habitat (Fig. 2).

\section{Discussion}

Acknowledging the inherent complexity of species distributions requires methods that are capable of accommodating real-world species associations. Here we used LVM to discern the joint distribution of species (see, e.g., $[1,7]$, showing that across a large intertidal area $\left(300,000 \mathrm{~m}^{2}\right)$ both positive and negative shared habitat preferences are abundant. Also, we demonstrated that positive and to some extend negative co-occurrences of species are common, particularly in bare sand flats.

Contrary to our expectations, seagrass meadows mainly structured benthic communities due to species having a shared habitat preference, whereas in bare sandflats species commonly displayed positive and negative co-occurrences in addition to shared habitat preferences. This might indicate that in a more obvious physically structured habitat, such as provided by seagrass meadows [11], provisioning of different niches leads to the observed community structure. Also, the physical structure of seagrass meadows might limit the mobility of some species like Austrovenus stutchburyi, as they can't bulldoze their way through the rhizome mat. Most species are also moving (especially in early benthic stages) associated with hydrodynamics and bedload transport and this effect will also be baffled by seagrass. In bare sand flats, which are often perceived as seemingly featureless habitats (but see [14]), community structure likely is more animal created, with greater dominance of interference competition and facilitation to mediate the impact of abiotic stress [15]. Such species interactions are critical in habitat modifications, influencing sediment compositions, hydrodynamics, and biogeochemistry, thereby impacting interaction networks, feedbacks and ecosystem functioning [16]. Lastly, how mobile animals perceive the mosaic of patterning might impact their dispersal through the seascape $[17,18]$.

As reviewed in detail by Dormann et al. [7] and in the introduction, we refrain from discussing our results in the context of biotic interactions. Given that assessing co-occurrences are based on residual correlations (e.g. [13, 19]), unmeasured environmental variables rather than biotic interactions might also explain observed patterns. We considered most commonly used habitat features to describe benthic community patterns (see, e.g., $[20,21])$ and we acknowledge that this data-driven approach offered hints on potential community organisation processes [19]. For example, random occurrences in seagrass meadows, as shown by the living attached to seagrass blades limpet Notoacmea scapha and the bulldozing predator/scavenging whelk Cominella glandiformis, might indicate a life-style utilizing other habitat features than the surrounding benthic fauna that mostly live buried in the sediment. In New Zealand intertidal systems, the suspension-feeding A. stutchburyi and the deposit-feeding Macomona liliana are key bioturbating bivalves regarding ecosystem architecture due to their sediment-dwelling life-style [16, 20, 22-24]. High densities of adult $M$. liliana negatively affect microphytobenthos and juveniles of many other species including conspecifics due to their grazing behaviour [24], and its negative co-occurrence with tube-building and sediment stabilizing polychaetes Macroclymenella stewartensis and Pseudopolydora 'fat' in seagrass meadows suggests such opposing "interests". The bivalve Nucula hartvigiana negatively co-occurred with, e.g., the polychaetes Aonides trifida and Magelona dakini, in intertidal sandflats. This might indicate subtle differences in habitat preferences, since $N$. hartvigiana tends to be in slightly muddy and organic rich sediments, whereas both polychaetes like more permeable low organic load sediments (e.g. $[25,26])$. The amphipod Paracalliope novizealandiae flits around at the sediment water interface, co-occurring with many species in both habitats, perhaps profiting from their sediment reworking activities to gather food.

\section{Conclusions}

Positive or negative co-occurrence of species, after considering habitat preferences, are common and are present beyond experimentally accessible spatial scales. This strengthens previous research aiming to resolve biodiversity-ecosystem functioning at seascape-scales, which noted the importance of scale considerations to understand structure and resilience of ecosystems [11, $15,21,27]$. In addition to underlining the spatial scale 
of community structure, our work shows the contextdependent nature of species co-occurrences, in which the higher relative importance of positive and negative co-occurrences in bare sand flats, harbouring to a greater extend the same species as neighbouring seagrass meadows, lead to a highly interconnected benthic network. These findings stress the critical importance of natural history to modelling, as well as incorporating ecological reality in SDMs.

From the management point of view, this work has important implications; frequently, bare sand bottoms are undervalued compared to, for example, reefs, which are considered of larger importance for conservation when taking decisions in coastal management (e.g. development of harbours, marinas, construction of pipelines). Nevertheless, our work shows that at least some bare sand bottoms harbour rich benthic communities with complex ecological interactions that are worth conserving.

\section{Methods}

\section{Empirical data}

To test whether the co-occurrence of species influences the structure of communities beyond experimental scales, we used data on macrobenthic fauna, mainly bivalves, polychaetes, and crustaceans, and environmental features from 400 sampling points arrayed across $300,000 \mathrm{~m}^{2}$ of intertidal sandflat in Kaipara Harbour, New Zealand [20,23]. Effectively these sampling points covered the complete intertidal sandflat exposed during low-tide. This enabled us to model spatial co-occurrences from $30 \mathrm{~cm}$ (smallest sampling distance) to $1 \mathrm{~km}$ (largest sampling distance). Specifically, we compared species distributed across starkly contrasting mosaics of seagrass patches (seagrass coverage at least 33\%; 63 sampling points; Additional file 1: Table S1), and bare intertidal sandflats ( $0 \%$ coverage of seagrass; 279 sampling points; Additional file 2: Table S2). In both habitats, separated by $30 \mathrm{~cm}$ up to $1 \mathrm{~km}$, we only considered species present in $>25 \%$ of the sampling locations (Table 1 for species names and occurrence information), to warrant sufficient power to assess species-to-species co-occurrences and to deal only with species ecologically associated with bare sand or seagrass habitats.

\section{Model description}

Latent variable models are extensions of multivariate regression models with unobserved ("latent") predictors that help to capture correlations or missing predictors (e.g. [28]). Since the among-species correlation matrix $\mathbf{u}$ has $N \times(N-1) / 2$ entries $(N$ being the number of species), which all need to be estimated, a trick is to represent the entries of $\mathbf{u}$ as a linear function of two or more latent variables, thereby reducing the number of parameters to be estimated (for details see [1]). LVMs are then formulated as mixed-effect models, in their simplest form assuming a Gaussian distribution of abundances, as:

$$
m_{\mathrm{ij}}=\beta_{\mathrm{oj}}+\mathbf{X}_{\mathrm{i}} \beta_{\mathrm{j}}+\mathbf{u}_{\mathrm{ij}}+\varepsilon_{\mathrm{i}}
$$

where $m_{\mathrm{ij}}$ is the abundance of species $j(j=1, \ldots, m)$ at location $i(i=1, \ldots, n), \beta_{\mathrm{oj}}$ is an intercept, $\mathbf{X}_{\mathrm{i}} \beta_{\mathrm{j}}$ represents the regression coefficients $\left(\beta_{j}\right)$ of environmental variables $\left(\mathbf{X}_{\mathrm{i}}\right)$ and $\varepsilon_{\mathrm{i}}$ are the regression residuals. $\mathbf{u}_{\mathrm{ij}}=\mathbf{z}_{\mathrm{i}} \lambda_{\mathrm{j}}$ and represents variation that can be captured by construction of new explanatory variables composed of latent variables $\left(\mathbf{z}_{\mathrm{i}}\right)$ and factor loadings $\left(\lambda_{\mathrm{j}}\right)$, which represent the strength of the relationship between latent variables and observed variables. These latent variables have resemblance to ordination axis $[1,12]$ and are treated as random factors to acknowledge they are unobserved.

\section{Analysis}

Following Dormann et al. [29], we only considered environmental variables with an $|\mathrm{r}|<0.7$ to avoid collinearity, choosing the overall least correlated variables for further analysis. Then we used the Watanabe-Akaike information criterion (WAIC; [30]) to define the most parsimonious model, based on all possible subsets. For seagrass areas this resulted in the inclusion of organic content of sediments (\%), sediment grain-size fraction $>500 \mu \mathrm{m}(\%)$, sediment grain-size fraction 125 $250 \mu \mathrm{m}(\%)$, sediment median grain size $(\mu \mathrm{m})$, and distance to shore $(\mathrm{m})$ as a proxy for inundation time. For bare sand habitats this included: distance to shore, sediment median grain-size, sediment grain size fraction $<63 \mu \mathrm{m}(\%)$, sediment grain-size fraction $>500 \mu \mathrm{m}$, organic content of sediments, and coverage of shell hash (i.e. broken shell fragments; \%). For continuous variables, we included quadratic functions to account for patchy distributions across the study site. All environmental variables were standardised to mean 0 and variance 1 [31].

We used Markov Chain Monte Carlo (MCMC) methods to run the LVMs, using JAGS [32] via the package BORAL [13] in $R$ [33], assuming a negative binomial distribution based on a quantile plot of Dunn-Smyth residuals. Default uninformative priors were used for all parameters in all models. We ran models allowing for two latent variables for 125,000 iterations, using a burnin of 25,000 iterations. Using more than two latent variables would have been possible, but preliminary model runs suggested that such was not necessary to capture patterns of species co-occurrences. R code for fitting and analysis of LVM are available from $[1,12,13]$. 


\section{Supplementary information}

Supplementary information accompanies this paper at https://doi. org/10.1186/s12898-020-00308-4.

Additional file 1: Table S1 CSV-file containing the species-occurrence information for seagrass habitats, as well as associated values for environmental variables.

Additional file 2: Table S2 CSV-file containing the species-occurrence information for sandy habitats, as well as associated values for environmental variables.

\section{Acknowledgements}

We thank colleagues at the National Institute for Water and Atmospheric research for support during field and lab-work.

\section{Authors' contributions}

CK, SFT and CFD conceived the study, designed the study, and drafted the manuscript. CK and SFT performed the field work and lab work. SFT and CFD contributed to data analysis, carried out by CK. All authors read and approved the final manuscript.

\section{Funding}

This research was supported by the Marsden Fund of the Royal Society of New Zealand (NIW-1 102) to SFT and CK, and a Marie-Curie fellowship (Grant 700796) to CK. The funding bodies were not involved in the design of the research question, field data collection, analysis and interpretation of data, or writing the manuscript.

\section{Availability of data and materials}

The datasets supporting this article have been uploaded as part of the additional files.

\section{Ethics approval and consent to participate}

We obtained permission to access intertidal areas and conduct sampling from local Maori representatives, as well as a Ministry for Primary Industries (MPI) Special Permit to National Institute of Water \& Atmospheric Research Ltd, also covering students, representatives and employees as part of their association with the permit holder.

\section{Consent for publication}

Not applicable.

\section{Competing interests}

The authors declare that they have no competing interests.

\section{Author details}

${ }^{1}$ Helmholtz Institute for Functional Marine Biodiversity At the University of Oldenburg, Ammerländer Heerstraße 231, 23129 Oldenburg, Germany. ${ }^{2}$ Department of Functional Ecology, Alfred Wegener Institute Helmholtz Centre for Polar and Marine Research, Am Handelshafen 12, 27570 Bremerhaven, Germany. ${ }^{3}$ Institute of Marine Science, University of Auckland, Private Bag 92019, Auckland 1142, New Zealand. ${ }^{4}$ Biometry and Environmental System Analysis, University of Freiburg, Tennenbacherstr. 4, 79106 Freiburg, Germany. ${ }^{5}$ Present Address: Thünen Institute of Sea Fisheries, Herwigstraße 31, 27572 Bremerhaven, Germany.

Received: 5 November 2019 Accepted: 4 July 2020

Published online: 08 July 2020

\section{References}

1. Warton DI, Blanchet FG, O'Hara RB, Ovaskainen O, Taskinen S, Walker SC, Hui FKC. So many variables: joint modeling in community ecology. Trends Ecol Evol. 2015;30:766-79. https://doi.org/10.1016/j.tree.2015.09.007.

2. Pollock LJ, Tingley R, Morris WK, Golding N, O'Hara RB, Parris KM, Vesk PA, McCarthy MA. Understanding co-occurrence by modelling species simultaneously with a joint species distribution model (JSDM). Methods Ecol Evol. 2014;5:397-406. https://doi.org/10.1111/2041-210X.12180.

3. Wisz MS, et al. The role of biotic interactions in shaping distributions and realised assemblages of species: implications for species distribution modelling. Biol Rev. 2012;88:15-30. https://doi.org/10.1111/j.1469185X.2012.00235.X.

4. Tylianakis JM, Didham RK, Bascompte J, Wardle DA. Global change and species interactions in terrestrial ecosystems. Ecol Lett. 2008;11:1351-63. https://doi.org/10.1111/j.1461-0248.2008.01250.x.

5. Kissling WD, et al. Towards novel approaches to modelling biotic interactions in multispecies assemblages at large spatial extents. J Biogeogr. 2012;39:2163-78. https://doi.org/10.1111/j.1365-2699.2011.02663.X.

6. Pellissier L, Bråthen K, Pottier J, Randin CF, Vittoz P, Dubuis A, Yoccoz NG, Alm T, Zimmermann NE, Guisan A. Species distribution models reveal apparent competitive and facilitative effects of a dominant species on the distribution of tundra plants. Ecography. 2010;33:1004-14. https:// doi.org/10.1111/j.1600-0587.2010.06386.x.

7. Dormann $C F$, et al. Biotic interactions in species distribution modelling: ten questions to guide interpretation and avoid false conclusions. Glob Ecol Biogeogr. 2018;27:1004-166. https://doi.org/10.1111/geb.12759.

8. Rohde K. Nonequilibrium ecology. Cambridge: Cambridge University Press; 2005.

9. Menge BA. Indirect effects in marine rocky intertidal interaction webs: patterns and importance. Ecol Monogr. 1995;65:21-74. https://doi. org/10.2307/2937158

10. Boström C, Pittman SJ, Simenstad C, Kneib RT. Seascape ecology of coastal biogenic habitats: advances, gaps, and challenges. Mar Ecol Progr Ser. 2011;427:191-21818. https://doi.org/10.3354/meps09051.

11. van de Koppel J, van der Heide T, Altieri A, Eriksson Bouma Olff Silliman BKTHBR. Long-distance interactions regulate the structure and resilience of coastal ecosystems. Ann Rev Mar Sci. 2015;7:139-58. https://doi. org/10.1146/annurev-marine-010814-015805.

12. Wilkinson DP, Golding N, Guillera-Arroita G, Tingley R, McCarthy MA. A comparison of joint species distribution models for presenceabsence data. Methods Ecol Evol. 2019;10:198-21111. https://doi. org/10.1111/2041-210X.13106.

13. Hui FKC. Boral - Bayesian ordination and regression analysis of multivariate abundance data in R. Methods Ecol Evol. 2016;7:744-50. https://doi. org/10.1111/2041-210X.12514.

14. Hewitt JE, Thrush SF, Halliday J, Duffy C. The importance of small-scale habitat structure for maintaining beta diversity. Ecology. 2005;86:161926. https://doi.org/10.1890/04-1099.

15. Bruno JF, Stachowicz JJ, Bertness MD. Inclusion of facilitation into ecological theory. Trends Ecol Evol. 2003;18:119-25. https://doi.org/10.1016/ S0169-5347(02)00045-9.

16. Thrush SF, et al. Experimenting with ecosystem interaction networks in search of threshold potentials in real world marine ecosystems. Ecology. 2014;95:1451-7. https://doi.org/10.1890/13-1879.1.

17. Wiens JA, Stenseth NC, Van Horne B, Ims RA. Ecological mechanisms and landscape ecology. Oikos. 1993;66:369-80. https://doi.org/10.2307/35449 31.

18. Wiens JA. Spatial scaling in ecology. Funct Ecol. 1989;3:385-97. https:// doi.org/10.2307/2389612

19. Ovaskainen O, Tikhonov G, Norberg A, Blanchet FG, Duan L, Dunson D, Roslin T, Abrego N. How to make more out of community data? A conceptual framework and its implementation as models and software. Ecol Lett. 2017;20:561-76. https://doi.org/10.1111/ele.12757.

20. Kraan C, Dormann CF, Greenfield BL, Thrush SF. Cross-scale variation in biodiversity-environment links illustrated by coastal sandflat communities. PLoS ONE. 2015;10:e014241. https://doi.org/10.1371/journ al.pone.0142411.

21. Thrush SF, Hewitt JE, Kraan C, Lohrer AM, Pilditch AM, Douglas EJ. Changes in the location of biodiversity-ecosystem function hot spots across the seafloor landscape with increasing sediment nutrient loading. Proc Royal Soc London B Biol Sci. 2017;284:20162861. https://doi. org/10.1098/rspb.2016.2861.

22. Jones HFE, Pilditch CA, Bryan KR, Hamilton DP. Effects of infaunal bivalve density and flow speed on clearance rates and near-bed hydrodynamics. J Exp Mar Biol Ecol. 2011;401:20-8. https://doi.org/10.1016/j.jembe 2011.03 .006 
23. Greenfield BL, Kraan C, Pilditch CA, Thrush SF. Spatial variation of functional group diversity in estuarine benthic communities. Mar Ecol Progr Ser. 2016:548:1-10. https://doi.org/10.3354/meps11692.

24. Thrush SF, et al. Matching the outcome of small-scale density manipulation experiments with larger scale patterns: an example of bivalve adult/ juvenile interactions. J Exp Mar Biol Ecol. 1997;216:153-69. https://doi. org/10.1016/S0022-0981(97)00094-4.

25. Thrush SF, Hewitt JE, Hickey CW, Kelly S. Multiple stressor effects identified from species abundance distributions: Interactions between urban contaminants and species habitat relationships. J Exp Mar Biol Ecol. 2008;366:160-8. https://doi.org/10.1016/j.jembe.2008.07.020.

26. Thrush SF, Hewitt JE, Norkko A, Nicholls PE, Funnell GA, Ellis JI. Habitat change in estuaries: predicting broad-scale responses of intertidal macrofauna to sediment mud content. Mar Ecol Progr Ser. 2003;263:101-12. https://doi.org/10.3354/meps263101.

27. Lohrer AM, Thrush SF, Hewitt JE, Kraan C. The up-scaling of ecosystem functions in a heterogeneous world. Sci Rep. 2015;5:10349. https://doi. org/10.1038/srep10349.

28. Ovaskainen O, Roy DB, Fox R, Anderson BJ. Uncovering hidden spatial structure in species communities with spatially explicit joint species distribution models. Methods Ecol Evol. 2016;7:428-36. https://doi. org/10.1111/2041-210X.12502.

29. Dormann CF, et al. Collinearity: a review of methods to deal with it and a simulation study evaluating their performance. Ecography. 2012;35:1-20. https://doi.org/10.1111/j.1600-0587.2012.07348.x.

30. Gelman A, Hwang J, Vehtari A. Understanding predictive information criteria for Bayesian models. Stat Comput. 2014;24:997-1016. https://doi. org/10.1007/s11222-013-9416-2.

31. Gelman A, Hill J. Data analysis using regression and multilevel/hierarchical models. Cambridge, UK: Cambridge University Press; 2007.

32. Plummer M. 2003 JAGS: A program for analysis of Bayesian graphical models using Gibbs sampling. In: Proceedings of the 3rd International Workshop on Distributed Statistical Computing. Vol. 124, pp. 20-22.

33. R Development Core Team. R: a language and environment for statistical computing. Vienna: R Foundation for Statistical Computing; 2015

\section{Publisher's Note}

Springer Nature remains neutral with regard to jurisdictional claims in published maps and institutional affiliations.
Ready to submit your research? Choose BMC and benefit from:

- fast, convenient online submission

- thorough peer review by experienced researchers in your field

- rapid publication on acceptance

- support for research data, including large and complex data types

- gold Open Access which fosters wider collaboration and increased citations

- maximum visibility for your research: over $100 \mathrm{M}$ website views per year

At BMC, research is always in progress.

Learn more biomedcentral.com/submissions 